\title{
Multidimensional approach to iron deficiency anemia in infants younger than two years old in Northeast Argentina. 2004-2005
}

\author{
Mariana A. Falivene, M.D. ${ }^{a}$ and Gisel L. Fattore, M.D. ${ }^{b}$
}

\begin{abstract}
Introduction. The prevalence of iron deficiency anemia (IDA) is high among infants younger than two years old, especially in disadvantaged populations.

Objective. To study certain social and biological determinants associated with IDA in children aged 12 to 23.9 months old in Northeast Argentina in the 2004-2005 period.

Methodology. Cross-sectional design. Explanatory outcome measures were organized in three levels: distal (food assistance, unmet basic needs, and head of household with medical coverage), intermediate (breastfeeding, iron supplementation, and iron intake), and proximal (nutritional status, gestational age, birth weight, age, and sex). The association between selected outcome measures and IDA $(\mathrm{Hb}<11 \mathrm{~g} / \mathrm{dL}$, ferritin $<12 \mathrm{ng} / \mathrm{dL}, \mathrm{WBCs}<15000 / \mathrm{mL}$ ) was assessed using logistic regression models with hierarchical selection of outcome measures.

Results. Lack of food assistance (OR: 1.85 [1.14, 3.02]) and inadequate iron intake (OR: 2.60 [1.18, 5.71]) were associated with IDA. The prevalence of anemia was higher with a younger gestational age (OR: $0.89[0.81,0.97])$ and a younger age in months old (OR: 0.90 [0.84, 0.96]).

Conclusions. This study evidences the strong and complex relationship between social determinants and anemia, a disease that is highly prevalentamongyoung children. Food assistance programs may have a protective effect against IDA; consumption of fortified foods may improve iron intake in infants younger than two years old. In addition, emphasis is placed on the need to assess the impact of policies on population health. Key words: iron deficiency anemia, socioeconomic factors, gestational age, infant.
\end{abstract}

http:/ /dx.doi.org/10.5546/aap.2016.eng.14

\section{INTRODUCTION}

Iron deficiency anemia (IDA) is Mariana A. Falivene, M.D.: marianafalivene@ hotmail.com

Funding:

Ministry of Health of the Province of Chaco.

Conflict of interest: None.

Received: 7-3-2015 Accepted: 9-2-2015 may be the result of economic development. $^{2}$

Multiple factors may explain the high prevalence that has been recorded in this region, including biological factors, such as prematurity, low birth weight and nutrient deficiency. ${ }^{3-5}$ However, regional inequalities cannot be accounted for based only on a biological perspective.

Therefore, in order to better understand this phenomenon, it is necessary to include social determinants into the conceptual framework of the health-disease process, and create visibility for the causes that lead to major differences in population health status, a subject many times overlooked..$^{6-9}$

The final report published by the Commission on Social Determinants of Health in 2008 indicates that the chance of illness and the risk of premature death are not only natural, but are also generated at a social level, so they should be avoided. ${ }^{10}$ The description and explanation of the health-disease process have opened up a space for confrontation with more comprehensive conceptual and methodological advances. ${ }^{11,12}$

From this perspective, studying the causes requires adopting a theoretical model that relates and articulates factors that contribute to their biological and social determination.

The objective of this study was to assess the effect of certain social and biological determinants of health on IDA in children aged between 12 and 23.9 months old in the NEA region in the 2004-2005 period using a hierarchical approach.

\section{MATERIAL AND METHODS}

A cross-sectional study was 
conducted with data obtained from the National Survey on Nutrition and Health (Encuesta Nacional de Nutrición y Salud, ENNyS) ${ }^{2}$ administered during 2004 and 2005 in the NEA region (Chaco, Formosa, Misiones and Corrientes). Figure 1 shows the selection of study subjects.

In accordance with the proposal to use social determinants, a conceptual model was designed. Outcome measures were selected based on a hierarchical scheme similar to that proposed by Silva, et al. ${ }^{4}$ This model considers interrelationships among the determinants of anemia grouped into three blocks (Figure 2). The distal block described the population's social and economic policies. It was made up of the following outcome measures: unmet basic needs (UBNs), ${ }^{13}$ head of household with medical coverage, and total food assistance (TFA). ${ }^{2}$ The latter was defined as families who referred to have received a bag or box of groceries, food coupons or vouchers issued by a food program, and/or fluid or powder milk or who indicated to have attended a soup kitchen in the past 90 days. The intermediate block of determinants included maternal care practices and was made up by the following outcome measures: breastfeeding, medicinal iron supplementation, and adequate iron intake. ${ }^{2}$ The proximal block included indirect determinants, such as gestational age (GA), birth weight and the infant's anthropometric outcome measures, which may be associated with maternal health and nutritional status and can be modified, and direct determinants, such as age and sex, which are biological characteristics that cannot be modified.

Such hierarchical structure assigned to outcome measures allowed to understand events by incorporating social context and establishing a logical order for outcome measure inclusion into the model. ${ }^{4,5,11}$ Table 1 shows the operationalization of the studied outcome measures.

The association between IDA and explanatory outcome measures was initially studied using a bivariate analysis, with Pearson's test and the $\chi^{2}$ test if the corresponding assumptions were met, or with Fisher's exact test, if they were not. The Wilcoxon test was used for independent samples to study differences between IDA and the birth weight and age in months old continuous quantitative outcome measures; and the median test was used for the GA outcome measure.

A logistic regression analysis was done to assess direct effects of distal, intermediate and proximal determinants on IDA and select outcome measures to be included in the model. During this first stage, outcome measures were introduced separately in each block of determinants; those associated to a significance level $<0.05$ remained in the model.

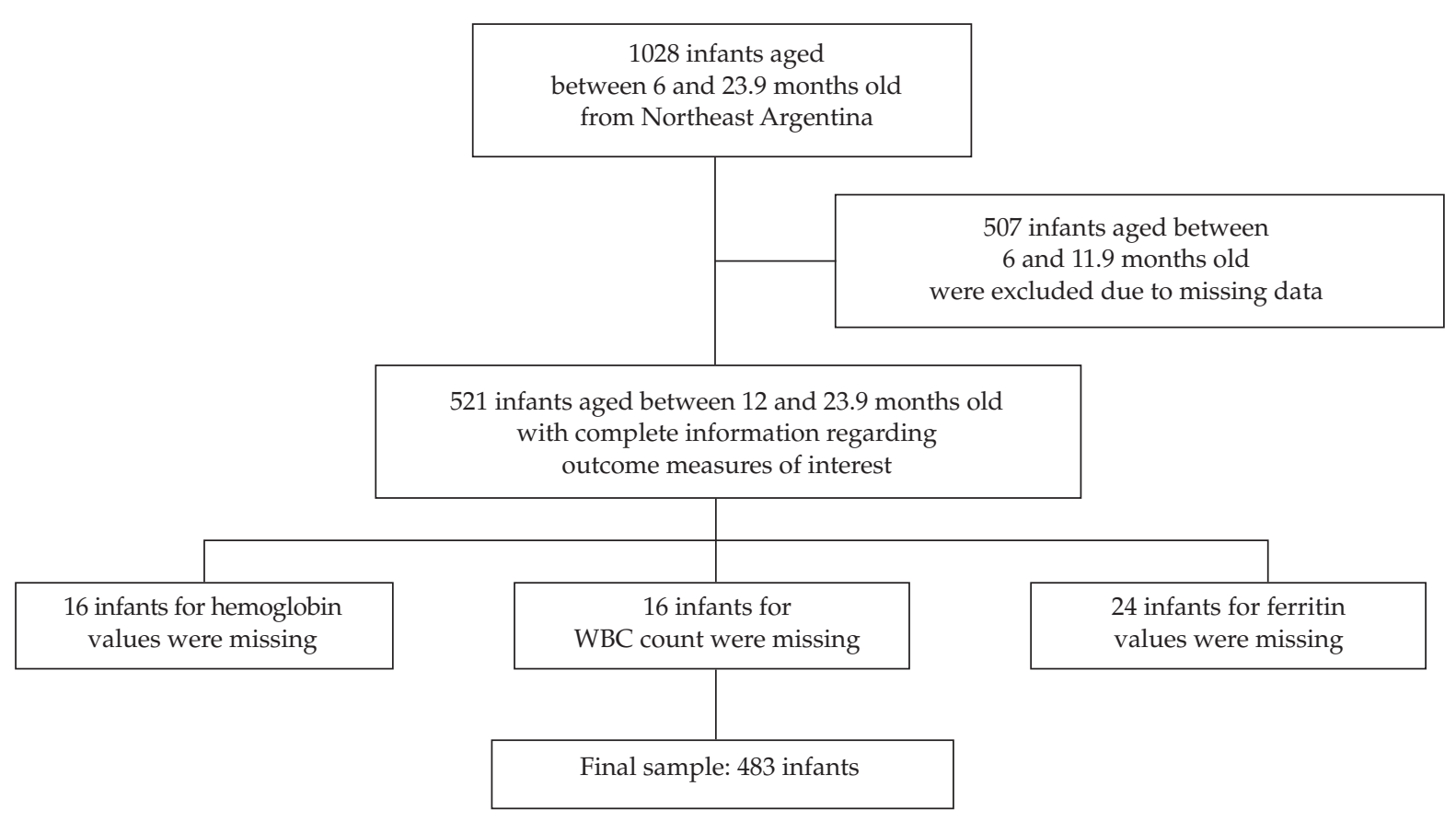

IDA: iron deficiency anemia. 
During the second stage, and in order to assess whether the effect of distal determinants was mediated by intermediate and proximal determinants, a multiple logistic regression (MLR) analysis with hierarchical selection of outcome measures was developed following the sequence in Figure 2. Thus, based on distal outcome measures that showed a statistical association, outcome measures from the intermediate block that showed an association in the previous stage were included. The same strategy was applied to introduce outcome measures in the other levels. ${ }^{4}$ The final model was made up of outcome measures from each block that showed a significant association with anemia.

Results were expressed based on odds ratios (ORs) and their corresponding confidence intervals (CIs). A $p$ value $<0.05$ was considered statistically significant in all cases. ${ }^{14,15}$ A HosmerLemeshow test was used to assess model fit. Data were processed using the statistical software SPSS version 18.0.

TABLE 1. Definitions and operationalization of the studied outcome measures

\begin{tabular}{|c|c|c|c|c|}
\hline & Outcome measure & Indicators & Categorización & Category \\
\hline $\begin{array}{l}\text { Dimension of the IDA } \\
\text { dependent } \\
\text { outcome measure }\end{array}$ & $\begin{array}{l}\text { IDA }(\mathrm{Hb}<11 \mathrm{~g} / \mathrm{dL}, \\
\text { ferritin }<12 \mathrm{ng} / \mathrm{dL}, \\
\text { WBCs }<15000 \mathrm{~mL})\end{array}$ & $\begin{array}{l}\text { Hemoglobin in } \mathrm{g} / \mathrm{dL} \\
\text { Ferritin in } \mathrm{ng} / \mathrm{mL} \\
\text { WBC count }\end{array}$ & $\begin{array}{l}\text { 0: No IDA } \\
\text { 1: IDA }\end{array}$ & Nominal \\
\hline Distal block & Outcome measures & Indicators & Category & Scale \\
\hline $\begin{array}{l}\text { Social and economic } \\
\text { factors that } \\
\text { characterize } \\
\text { an individual or group } \\
\text { within the social } \\
\text { structure (DeCS) }\end{array}$ & $\begin{array}{c}\text { Medical coverage } \\
\text { of the head of household } \\
\text { TFA }\end{array}$ & $\begin{array}{l}\text { Home with UBNs } \\
\text { Type of medical coverage } \\
\text { of the head of household } \\
\text { TFA }\end{array}$ & $\begin{array}{c}\text { 0: home with no UBNs } \\
\text { 1: home with UBNs } \\
\text { 0: public } \\
\text { 1: other (private, social security) } \\
\text { 0: receiving } \\
\text { 1: not receiving }\end{array}$ & $\begin{array}{l}\text { Nominal } \\
\text { Nominal } \\
\text { Nominal }\end{array}$ \\
\hline $\begin{array}{l}\text { 1FA: total food assistanc } \\
\text { Intermediate block }\end{array}$ & Outcome measures & Indicators & Category & Scale \\
\hline \multirow[t]{3}{*}{$\begin{array}{l}\text { Maternal care } \\
\text { practices }\end{array}$} & Breastfeeding & $\begin{array}{l}\text { Breastfeeding practice } \\
\text { at the time of the survey }\end{array}$ & $\begin{array}{c}\text { 0: yes, breastfed } \\
\text { and/or breastfeeding } \\
\text { 1: no breastfeeding ever }\end{array}$ & Nominal \\
\hline & $\begin{array}{l}\text { Medicinal iron } \\
\text { supplementation }\end{array}$ & $\begin{array}{l}\text { Iron supplementation } \\
\text { at the time of the survey }\end{array}$ & $\begin{array}{c}\text { 0: yes, received } \\
\text { and/or receiving } \\
\text { supplementation } \\
\text { 1: no supplementation ever }\end{array}$ & Nominal \\
\hline & Iron intake & Inadequate iron intake & $\begin{array}{l}\text { 0: no (> } 11 \mathrm{mg} / \text { day }) \\
\text { 1: sí (<11 mg/day) }\end{array}$ & Nominal \\
\hline
\end{tabular}

Iron intake: see reference from the ENNyS (bibliographic citation 2).

TFA: total food assistance DeCS: health sciences descriptors.

\begin{tabular}{|c|c|c|c|c|}
\hline Proximal block & Outcome measures & Indicators & Category & Scale \\
\hline $\begin{array}{l}\text { Anthropometric } \\
\text { assessment of } \\
\text { nutritional status }\end{array}$ & $\begin{array}{l}\text { Anthropometric } \\
\text { assessment of } \\
\text { nutritional status }\end{array}$ & $\begin{array}{c}\text { LWH }(\mathrm{z} W / \mathrm{H}<-2) \\
\text { LHA }(\mathrm{z} \mathrm{H} / \mathrm{A}<-2) \\
\text { LWA }(\mathrm{z} W / \mathrm{A}<-2)\end{array}$ & $\begin{array}{l}0: \text { no } 1: \text { yes } \\
0: \text { no 1: yes } \\
0: \text { no 1: yes }\end{array}$ & $\begin{array}{l}\text { Nominal } \\
\text { Nominal } \\
\text { Nominal }\end{array}$ \\
\hline \multicolumn{5}{|c|}{ WHO reference (see bibliographic citation 34). } \\
\hline Proximal block & Outcome measures & Indicators & Category & Scale \\
\hline Perinatal factors & $\begin{array}{c}\text { GA } \\
\text { Birth weight }\end{array}$ & $\begin{array}{c}\text { GA in weeks } \\
\text { Birth weight in grams }\end{array}$ & $\begin{array}{c}\text { GA in weeks } \\
\text { Birth weight in grams }\end{array}$ & $\begin{array}{l}\text { Continuous } \\
\text { Continuous }\end{array}$ \\
\hline \multirow[t]{2}{*}{ Demographic factors } & Sex & Sex & $\begin{array}{c}\text { Male } \\
\text { Female }\end{array}$ & Nominal \\
\hline & Infant's age & Age in months & Age in months & Continuous \\
\hline
\end{tabular}

IDA: iron deficiency anemia; TFA: total food assistance; UBNs: unmet basic needs; WHO: World Health Organization;

ENNyS: National Survey on Nutrition and Health; LWA: low weight for age; LHA: low height for age;

LWH: low weight for height; GA: gestational age.

DeCS: health sciences descriptors. 


\section{RESULTS}

Four hundred and eighty-three infants aged between 12 and 23.9 months old from the NEA region were studied. Their mean age was 18.1 months old $(S D \pm 3.63)$. Girls accounted for $48.7 \%$ of infants. Figure 3 summarizes the general characteristics of infants considering the blocks of outcome measures included in the study.

The prevalence of IDA was $19.7 \%$. More than $50 \%$ of the population had UBNs and received TFA, and most heads of households had a public medical coverage. In addition, most of the population referred to practice breastfeeding and iron supplementation; however, the level of inadequate iron intake was high among infants from the NEA region.

Table 2 shows the relationship between the prevalence of anemia and categorical outcome measures. In relation to continuous outcome measures, no differences were observed in birth weight among children with IDA and those who did not have IDA $(p=0.99)$. Median GA was lower in the anemia group (36 weeks) when compared to the no anemia group (38 weeks); this was a statistically significant difference. Differences in age distribution were also observed; the mean age among infants who did not have anemia was 18.4 months old ( $\mathrm{SD} \pm 3.63)$, while it was 17.31 months old $(\mathrm{SD} \pm 3.56)$ among infants with anemia $(p=0.01)$.
The results of the intra-block logistic regression analysis are shown in Table 3 . When analyzing distal outcome measures, TFA showed a strong association with anemia (OR: 2.09, 95\% CI: 1.25-3.47).

In relation to outcome measures in the intermediate block, breastfeeding and iron supplementation were not associated with IDA. Contrary to what was expected, in our study these preventive measures showed no protective effect, probably due to the minimum number of infants who had not been breastfed or had not received iron supplementation (Tables 2 and 4). However, an inadequate iron intake remained strongly associated with anemia (OR: 3.11, 95\% CI 1.44-6.72), i.e., infants with an inadequate iron intake were three times more likely to have anemia than those with an adequate iron intake. Anthropometric outcome measures (low weight for age [LWA], low height for age [LHA], low weight for height [LWH]) remained unassociated with IDA, as observed in the bivariate analysis.

In relation to the individual block, a younger GA (OR: 0.90, 95\% CI: 0.82-0.99) and a younger age in months old (OR: 0.91, 95\% CI: 0.86-0.97) were associated with a higher probability of having IDA. Birth weight and sex were not associated with IDA.

In order to assess to what extent the effect

FIGURE 2. Model for multidimensional determination of iron deficiency anemia in infants younger than two years old in Northeast Argentina. 2004-2005

Block corresponding to society's structural processes

Distal determinants

Block corresponding to the infant's immediate environment

Intermediate determinants

Block corresponding to the infant's individual processes Indirect proximal determinants

Direct proximal determinants

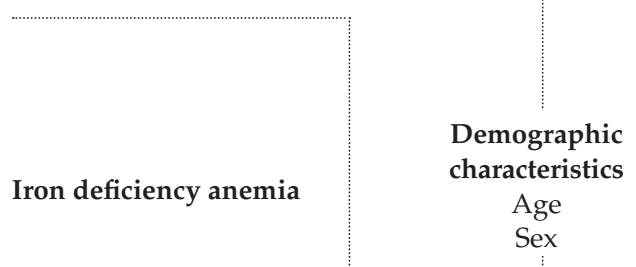

Model adapted from Silva, et al. (2001).

UBNs: unmet basic needs; GA: gestational age.
Socioeconomic characteristics UBNs

Food interventions Medical coverage

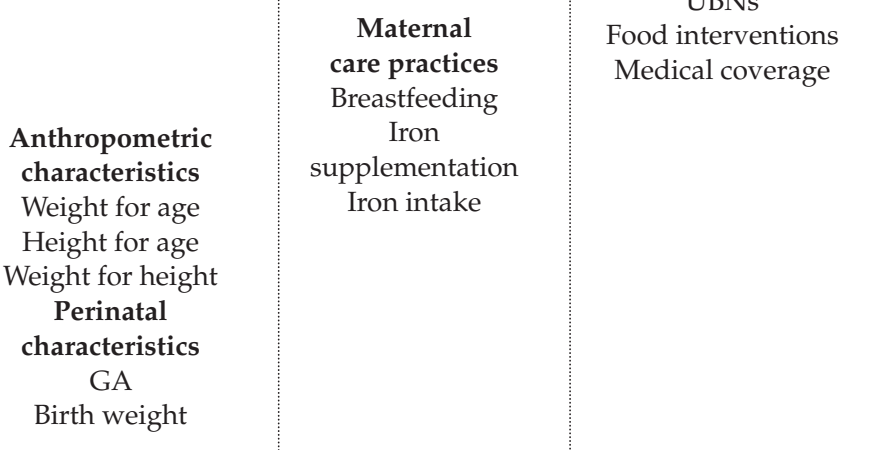




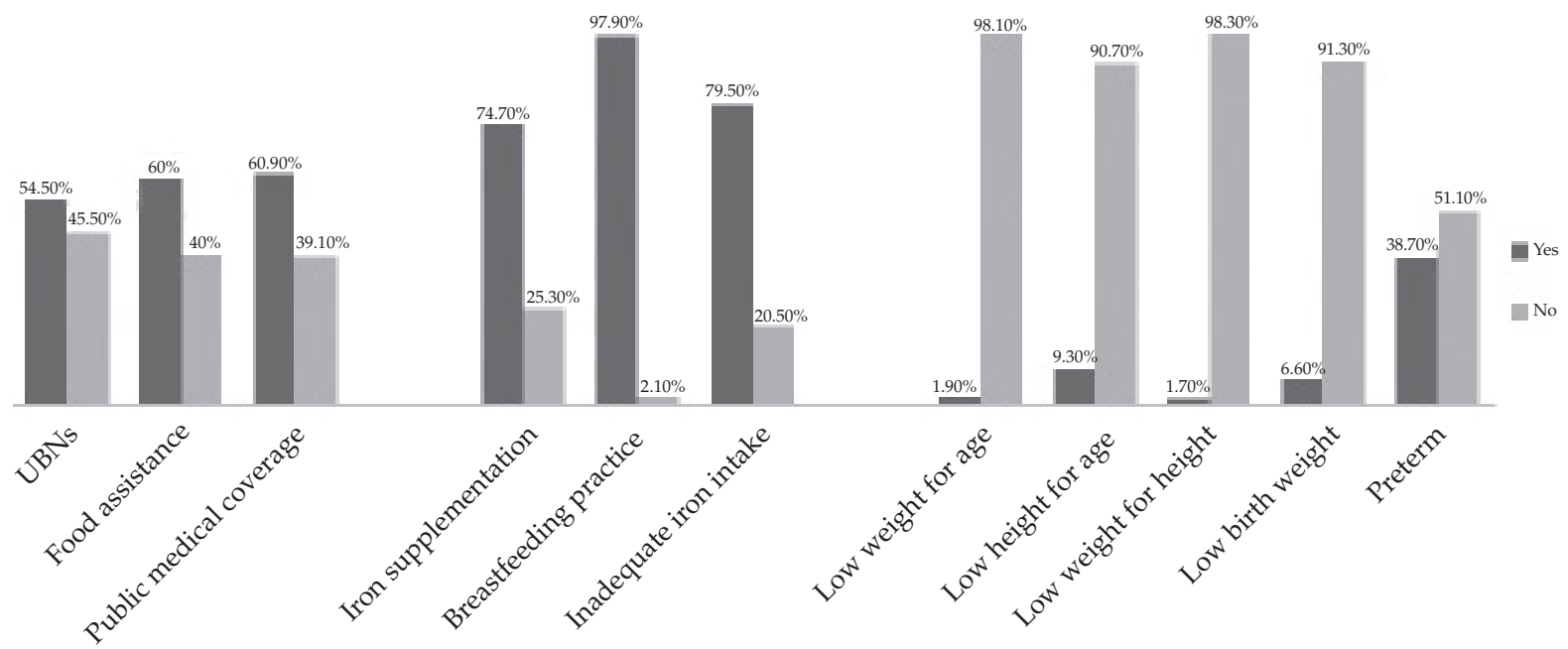

UBNs: unmet basic needs.

TABLE 2. Prevalence of iron deficiency anemia as per explanatory outcome measures in children from Northeast. Argentina. 2004-2005

\begin{tabular}{|c|c|c|c|c|}
\hline \multirow[b]{2}{*}{ Blocks } & & & \multicolumn{2}{|c|}{ IDA } \\
\hline & & & IDA n (\%) & No IDA n (\%)) \\
\hline \multirow[t]{6}{*}{ Distal } & UBNs & Yes & $48(18.3)$ & $215(81.7)$ \\
\hline & & No & $45(20.5)$ & $175(79.5)$ \\
\hline & Head of household with medical coverage & Public & $51(17.3)$ & $243(82.7)$ \\
\hline & & Other & $42(22.2)$ & $147(77.8)$ \\
\hline & $\mathrm{TFA}^{*}$ & Yes & $43(14.8)$ & $247(85.2)$ \\
\hline & & No & $50(25.9)$ & $143(74.1)$ \\
\hline \multirow[t]{6}{*}{ Intermediate } & Breastfeeding practice & Yes & $91(19.2)$ & $382(80.8)$ \\
\hline & & No & $2(20.0)$ & $8(80.0)$ \\
\hline & Iron supplementation & Yes & $63(17.5)$ & $298(82.5)$ \\
\hline & & No & $30(24.6)$ & $92(75.4)$ \\
\hline & Inadequate iron intake* & Yes & $85(22.1)$ & $299(77.9)$ \\
\hline & & No & $8(8.1)$ & 91 (91.9) \\
\hline \multirow[t]{6}{*}{ Indirect proximal } & LWA & Yes & $3(33.3)$ & $6(66.7)$ \\
\hline & & No & $90(19.0)$ & $384(81.0)$ \\
\hline & LHA & Yes & 7 (15.6) & $38(84.4)$ \\
\hline & & No & $86(19.6)$ & $352(80.4)$ \\
\hline & LWH & Yes & $1(12.5)$ & $7(87.5)$ \\
\hline & & No & $92(19.4)$ & $383(80.6)$ \\
\hline \multirow[t]{2}{*}{ Direct proximal } & Sex & Female & 44 (18.7) & $191(81.3)$ \\
\hline & & Male & 49 (19.8) & $199(80.2))$ \\
\hline
\end{tabular}

$* p<0.05$.

IDA: iron deficiency anemia; UBNs: unmet basic needs; LWA: low weight for age; LHA: low height for age; LWH: low weight for height; TFA: total food assistance. 
of distal determinants on IDA prevalence was mediated by intermediate and proximal determinants, consecutive regression models were developed by sequentially introducing outcome measures according to a pre-established theoretical model and considering only outcome measures that showed a statistical association in the intra-block analysis.

This way, based on the TFA distal outcome measure, which showed an association with anemia, the inadequate iron intake outcome measure, from the intermediate block, was introduced. Both outcome measures showed an association with the occurrence of IDA (Table 4). Introducing inadequate iron intake into the model did not substantially change the OR of
TFA in relation to anemia (OR: 2.00-1.76). In this regard, we should ask ourselves whether infants receiving TFA are those with a more adequate dietary iron intake.

When analyzing the relationship between inadequate iron intake and TFA using a bivariate analysis, a clear disproportion was observed between the percentage of infants receiving TFA and who had adequate iron intake $(79.8 \%)$ and those who did not receive TFA (20\%), which evidenced a strong relationship between both outcome measures $(p<0.05)$. However, after excluding the effect of iron intake, the TFA outcome measure continued to be associated with IDA, i.e., only part of the strong association between the TFA outcome measure and IDA

TABLE 3. Multivariate logistic regression analysis of independent outcome measures as per iron deficiency anemia in children from Northeast Argentina. 2004-2005

\begin{tabular}{llcc}
\hline Blocks & & Adjusted OR & (95\% CI) \\
\hline Socioeconomic & TFA* & 2.09 & $1.25 ; 3.47$ \\
& UBNs & 1.25 & $0.73 ; 2.12$ \\
Maternal care practices & Head of household with coverage & 1.18 & $0.72 ; 1.98$ \\
& Breastfeeding & 1.04 & $0.19,4.65$ \\
& Iron supplementation & 1.32 & $0.80,2.19$ \\
Nutritional & Iron intake* & 3.11 & $1.44,6.72$ \\
& LWA & 3.36 & $0.68,6.49$ \\
Individual & LHA & 0.57 & $0.22,1.48$ \\
& LWH & 0.46 & $0.52,4.05$ \\
Demographic & GA* & 0.90 & $0.82-0.99$ \\
& Birth weight & 1.00 & $1.00,1.00$ \\
& Sex & 0.87 & $0.55,1.37$ \\
\hline
\end{tabular}

* $p<0.05$; OR: odds ratio; 95\% CI: 95\% confidence interval. (Hosmer-Lemeshow test > 0.05). TFA: total food assistance; UBNs: unmet basic needs; LWA: low weight for age; LHA: low height for age; LWH: low weight for height; GA: gestational age.

TABLE 4. Logistic regression analysis of anemia determinants in infants aged between 12 and 24 months old in Northeast Argentina as per a model with hierarchical selection of explanatory outcome measures. 2004-2005

\begin{tabular}{|c|c|c|c|c|c|c|c|c|}
\hline \multirow[t]{2}{*}{ Blocks } & \multicolumn{2}{|c|}{ Stage 1} & \multicolumn{2}{|c|}{ Stage 2} & \multicolumn{2}{|c|}{ Stage 3} & \multicolumn{2}{|c|}{ Stage 4} \\
\hline & OR & $95 \%$ CI & OR & $95 \%$ CI & OR & $95 \%$ CI & OR & $95 \%$ CI \\
\hline $\begin{array}{l}\text { Distal } \\
\text { TFA }\end{array}$ & 2.00 & $1.27-3.17$ & 1.76 & $1.10-2.80$ & 1.82 & $1.12-2.95$ & 1.85 & $1.14-3.02$ \\
\hline $\begin{array}{l}\text { Intermediate } \\
\text { Inadequate iron intake }\end{array}$ & & & 2.81 & $1.29-6.08$ & 2.68 & $1.22-5.88$ & 2.60 & $1.18-5.71$ \\
\hline $\begin{array}{l}\text { Indirect proximal } \\
\text { GA }\end{array}$ & & & & & 0.90 & 0.83-0.99 & 0.89 & $0.81-0.97$ \\
\hline $\begin{array}{l}\text { Direct proximal } \\
\text { Age in months }\end{array}$ & & & & & & & 0.90 & 0.84-0.9 \\
\hline
\end{tabular}

OR: odds ratio; 95\% CI: 95\% confidence interval. (Hosmer-Lemeshow test > 0.05). TFA: total food assistance; GA: gestational age. 
may be the result of iron intake. In addition, no interaction between both outcome measures was observed (likelihood test, $p=0.57$ ).

Introducing the GA outcome measure from the indirect proximal block did not affect the association between TFA and IDA. The TFA and iron intake outcome measures remained associated with IDA, as well as the GA outcome measure, which continued to be associated (OR: 0.90, 95\% CI: $0.83-0.99)$. According to this analysis, the prevalence of anemia was reduced 0.90 times with each additional week of GA.

Lastly, based on the model made up of statistically significant outcome measures from the distal, intermediate and indirect proximal blocks, the outcome measure age in months old, from the indirect proximal block, was included. Results show that age in months old remained associated with anemia (OR: 0.90, 95\% CI: 0.840.96). No major changes occurred in TFA, iron intake and GA.

\section{DISCUSSION}

Our study revealed that the prevalence of anemia was higher in the group of children who did not receive food assistance. This evidences the beneficial effects of food assistance programs on infant health, already demonstrated in other studies conducted in Latin America. ${ }^{16-19}$

However, it is worth noting that, in Argentina, following the 2001 economic crisis, traditional food policies (e.g., programs that distributed bags or boxes of groceries among households) were concurrent with the implementation of the food fortification law (Law no. 25630), ${ }^{20}$ which established mandatory wheat flour fortification with iron and folic acid. In this regard, we wonder whether the effect of TFA on IDA prevalence is the result of such food fortification. Food fortification with multiple micronutrients is an effective intervention to reduce anemia in children and, according to some authors, it is comparable to daily iron supplementation. ${ }^{21}$ However, in our analysis, differences were observed between infants who received food assistance and those who did not; this means that, in spite of the present/past universal fortification of certain food, the prevalence of anemia among infants who received food assistance was lower, which evidences that not only food quality matters; it is necessary that the most disadvantaged populations receive good-quality fortified foods.

Regarding the other socioeconomic outcome measures, such as head of household with medical coverage and UBNs, no differences in the prevalence of IDA were observed. A possible explanation for this is the high prevalence of such factors in the study sample. The fact that these indicators of poverty are so common in this population may reduce the strength of the effects caused by the socioeconomic setting on anemia. ${ }^{22}$ Other socioeconomic status indicators are necessary to assess such association in greater depth.

Iron supplementation and breastfeeding were not associated with anemia. Consistent with our results, Domellöf refers that there is not enough evidence available to support the fact that administration of iron supplementation in healthy infants and young children with a normal birth weight reduces the prevalence of anemia. ${ }^{23}$

Besides, the protective effect of breastfeeding if more evident in the first six months of life. As of this age, consumption of other food plays a key role in the compliance of iron intake requirements. ${ }^{24,25}$ The lack of association between anemia and iron supplementation and breastfeeding practice may also be the result of the minimum number of infants included in the sample who received neither iron supplementation nor were breastfed. As described in other studies, ${ }^{26,27}$ we observed that the prevalence of anemia was higher in the group of infants who had an inadequate iron intake. We should not overlook the fact that this is associated with the type of food consumed by children. Although it is not possible to establish a direct causal relationship between infants with a more adequate iron intake and food assistance, it may be assumed that consuming the fortified food provided by food assistance programs may improve iron intake, which is reflected in better hematological parameters, as observed in this study. However, part of an adequate iron intake cannot be explained by the consumption of fortified foods. Other authors who assessed food consumption in infant populations who have a high prevalence of anemia showed that children who had fortified food had a lower prevalence of anemia. ${ }^{16-19,26}$ Once again, this underscores the importance of feeding in this age group.

Anthropometric outcome measures were not associated with anemia. Nevertheless, some authors found a direct correlation between serum iron levels and a low weight for age and a low height for age. ${ }^{27,28}$ In addition, preterm infants had a higher prevalence of IDA, which may be related to their lower iron stores at birth and, at 
the same time, a greater iron requirement during growth. ${ }^{29}$ In our study, a low birth weight was not associated with anemia.

In addition, as observed by other authors, 5,28,30 in our study younger infants were more likely to have IDA, which may be explained by a higher growth rate in this age group. No association was observed between sex and IDA; even so, Domellöf referred that boys had greater iron requirements. ${ }^{31}$

Several limitations should be contemplated in this study: all infants whose medical records did not provide data related to the IDA outcome measure were excluded; for this reason, the sample size was reduced. However, based on the studied sample, results with an acceptable dispersion range were obtained. Some outcome measures had a scarce number of values for the exposure category, which rendered the analysis association more difficult. The tool used here did not included data on maternal characteristics, perinatal aspects or parasitic infection. However, a higher prevalence of parasitic infections is observed with older age, as children start moving around and are not just restricted to their homes, as occurs with infants and toddlers. ${ }^{32,33}$ Lastly, the design of the sample used in this study is not a single randomization, and this may have implications for the corresponding confidence intervals and hypothesis testing.

\section{CONCLUSIONS}

IDA in children from the NEA area is associated with regional social and economic conditions.

The prevalence of IDA was lower among infants who received food assistance; this evidences that, in impoverished conditions, compensatory policies may have a positive impact on certain sensitive health conditions, such as anemia.

\section{Acknowledgments}

We would like to thank Débora Chan, B.S., Carlos Guevel, B.S., Enrique Abeyá Gilardon, M.D. and the director of the Pediatric Research and Development Institute, Horacio F. González, M.D.

\section{REFERENCES}

1. Lozoff B, Georgieff MK. Iron deficiency and brain development. Semin Pediatr Neurol 2006;13(3):158-65.

2. Argentina. Ministerio de Salud de la Nación. Encuesta Nacional de Nutrición y Salud. Documento de resultados 2007. [Accessedon: September 2, 2015]. Available at: http:/ /www.msal.gob.ar/images/stories/bes / graficos / 0000000257 cnt-a08-ennys-documento-deresultados-2007.pdf
3. World Health Organization. The global burden of disease: 2004 update. Geneva; 2008.

4. Silva LS, Giuglian ER, Aerts DR. Prevalência e determinante de anemia emcrianças de Porto Alegre, RS, Brasil. Rev Saude Publica 2001;35(1):66-73.

5. Neuman NA, Tanaka OY, Szarfarc SC, Guimarães PR, et al. Prevalência e fatores de risco para anemia no Sul do Brasil. Rev Saude Publica 2000;34(1):56-63.

6. Castellanos PL. Sobre el concepto salud-enfermedad. Un punto de vista epidemiológico. Cuad Med Soc (Ros) 1987;(42):15-24.

7. Moiso A. Determinantes de la salud. In: Barragán HL, Moiso A, Mestorino MA, Ojea OA, eds. Fundamentos de Salud Pública. La Plata: Edulp; 2007.Pages 161-89.

8. Castellanos PL. Sistemas nacionales de vigilancia de la situación de salud según condiciones de vida y el impacto de las acciones de salud y bienestar. Washington DC: Organización Panamericana de la Salud; 1991.

9. Laurell AC.El estudio social del proceso salud-enfermedad en América Latina. CuadMedSoc (Ros) 1986;(37):3-18.

10. Organización Mundial de la Salud. Determinantes sociales de la salud. Ginebra, 2005. [Accessed on: September 2, 2015]. Availableat:http://www.who.int/social_determinants/es/.

11. Victora CG, Huttly SR, Fuchs SC, Olinto MT. The role of conceptual frameworks in epidemiological analysis: a hierarchical approach. Int J Epidemiol 1997;26(1):224-7.

12. Ribeiro AM, Guimarães MJ, Lima Mde C, Sarinho $\mathrm{SW}$, et al. Fatores de risco para mortalidade neonatal emcriançascombaixo peso ao nascer. Rev Saude Publica 2009;43(2):246- 55.

13. Instituto Nacional de Estadística y Censos. Incidencia de la pobreza y la indigencia en los aglomerados urbanos, octubre 2002. Buenos Aires, 2003. [Accessed on: September 2, 2015]. Availableat: http:/ / www.indec.gov.ar/nuevaweb/ cuadros/74/pob_toct02.pdf.

14. Silva Aycaguer LC, Barroso Utra IM. Regresión logística. Cuadernos de estadística. Madrid: La Muralla; 2004.

15. Szklo M, Nieto FJ. Capítulo 5. La identificación de asociaciones no causales: confusión. In: Epidemiología intermedia. Conceptos y aplicaciones. Madrid: Díaz deSantos; 2003.Págs.155-60.

16. Rivera JA, Shamah T, Villalpando S, Monterrubio E. Effectiveness of a large-scale iron-fortified milk distribution program on anemia and iron deficiency in low-income young children in Mexico. Am J Clin Nutr 2010;91(2):431-9.

17. Hertrampf E, Olivares M, Brito A, Castillo-Carniglia A. Evaluación de la prevalencia de anemia ferropriva en una muestra representativa de la Región Metropolitana y Quinta Región de los beneficiarios del Programa Nacional de Alimentación Complementaria (PNAC). Santiago de Chile: Ministerio de Salud de Chile; 2009.

18. Bagni UV, Baião MR, Santos MM, Luiz RR, et al. Efeito da fortificação semanal do arroz com ferro quelato sobre a freqüência de anemia e concentração de hemoglobina emcrianças de crechesmunicipais do Rio de Janeiro, Brasil. Cad Saude Publica 2009;25(2):291-302.

19. Varea A, Malpeli A, Etchegoyen G, Vojkovic M, et al. Shortterm evaluation of the impact of a food program on the micronutrient nutritional status of Argentinean children under the age of six. Biol Trace Elem Res 2011;143(3):1337-48.

20. Ley 25630. Boletín Oficial de la República Argentina. Buenos Aires, 23 de agosto de 2002. [Accessed on: September 2, 2015]. Available at: http:/ /www.anmat.gov. ar/Legislacion/Alimentos/Ley_25630.pdf.

21. De-Regil LM, Suchdev PS, Vist GE, Walleser S, et al. Home fortification of foods with multiple micronutrient powders for health and nutrition in children under two years of age (Review). Evid Based Child Health 2013;8(1):112-201. 
22. López Pardo CM. Concepto y medición de la pobreza. Rev Cubana Salud Publica 2007;33(4).

23. Domellöf M, Braegger C, Campoy C, Colomb V, et al. Iron requirements of infants and toddlers. J Pediatr Gastroenterol Nutr 2014;58(1):119-29.

24. Robinson S, Marriott L, Poole J, Crozier S, et al. Dietary patterns in infancy: the importance of maternal and family influences on feeding practice. Br J Nutr 2007;98(5):1029-37.

25. Dube K, Schwartz J, Mueller MJ, Kalhoff H, et al. Iron intake and iron status in breastfed infants during the first year of life. Clin Nutr 2010;29(6):773-8.

26. Moshe G, Amitai Y, Korchia G, Korchia L, et al. Anemia and iron deficiency in children: association with red meat and poultry consumption. J Pediatr Gastroenterol Nutr 2013;57(6):722-7.

27. Olivares M, Hertrampf E, Chadud P. Anemia del lactante desnutrido marásmico. Rev Chil Pediatr 1992;63(4):191-5.

28. Morasso MD, Molero J, Vincour P, Acosta L, et al. Deficiencias de hierro y de vitamina A y prevalencia de anemia en niños y niñas de 6 a 24 meses de edad en Chaco, Argentina. Arch Latinoam Nutr 2003;53(1):21-7.

29. Olivares GM, Walter KT. Consecuencias de la deficiencia de hierro. Rev Chil Nutr 2003;30(3):226-33.
30. Silva DG, Priore SE, FranceschiniSdo C. Risk factors for anemia in infants assisted by public health services: the importance of feeding practices and iron supplementation. J Pediatr (Rio J) 2007;83(2):149-56.

31. Domellöf M, Lönnerdal B, Dewey KG, Cohen RJ, et al. Sex differences in iron status during infancy. Pediatrics 2002;110(3):545-52.

32. Ledesma AE, Fernández GJ. Enteroparasitosis: factores predisponentes en población infantil de la ciudad de Resistencia, Chaco. Corrientes: Universidad Nacional del Nordeste, 1994. [Accessedon: September 2, 2015]. Available at: http:/ / www.unne.edu.ar/unnevieja/Web/ cyt/com2004/3-Medicina/M-044.pdf.

33. Milano AM, Oscherov EB, Palladino AC, Bar AR. Enteroparasitosis infantil en un área urbana del nordeste argentino. Medicina (B Aires) 2007;67(3):238-42.

34. De Onis M, Onyango AW, Borghi E, Garza C, et al. Comparison of the World Health Organization (WHO) Child Growth Standards and the National Center for Health Statistics/WHO international growth reference: implications for child health programmes. Public Health Nutr 2006;9(7):942-7. 